\title{
Relationship Capital Knowledge about Developmental Cognitive Development Toddlers with a Toddler in Puskesmas Mungkajang Palopo
}

\author{
Santi $^{1}$, Abdul Gafur ${ }^{2}$ \\ ${ }^{1}$ Departement of Nursing, Institute of Health and Business Kurnia Jaya Persada, Maros, Indonesia \\ ${ }^{2}$ Departemen of Public Health, University of Pejuang Republik Indonesia, Makassar Indonesia
}

Corresponding Author: Abdul Gafur

\begin{abstract}
Quality of a child can be assessed by process of development. The development is one of the indicators in monitoring the health of child. Child development includes social personal development, motor, coarse language, and fine motor skills. It is estimated that more than 200 million children in developing countries fail to reach their optimal development potential due to poverty, malnutrition, or an unsupportive environment, which affects children's cognitive, motor, emotional, and social development.

This study aims to determine the relationship between mother's knowledge about growth and development of toddlers with cognitive development of toddlers in the working area of Mungkajang Health Center, Palopo city. The research design used a cross sectional study. The number of samples is 82 people.

The results of the study using the test chi-square showed that the $\mathrm{p}$-value $=0.000$ was smaller than the value of $=0.05$, which means that there is a relationship between mother's knowledge about growth and development of toddlers and cognitive development of toddlers in the working area of Mungkajang Public Health Center, Palopo City.

It is recommended for parents to always increase knowledge about child development so that children's cognitive development can be maximized.
\end{abstract}

Keywords: Knowledge of Growth and Development; Cognitive Development; Toddler

\section{BACKGROUND}

Quality of a child can be assessed by process of development. The development is one of the indicators in monitoring the health of child. Child development includes social personal development, motor, coarse language, and fine motor skills. In the ASEAN region, Indonesia is behind Singapore (ranked 33), Malaysia (ranked 65) and Thailand (ranked 84) but is still better than Myanmar (112), Cambodia (117) and Laos (130). Indonesia is ranked 101st as a country that provides opportunities for child development according to Save the Children's version of the Childhood Index 2017 report. The ranking concludes that not a few children in Indonesia have lost their childhood [1].

It is estimated that more than 200 million children in developing countries fail to reach their optimal development potential due to poverty, malnutrition, or an unsupportive environment, which affects children's cognitive, motor, emotional, and social development [2].

According to Indonesia's health profile data in 2018 , the number of children under five was $19,009,559$ out of a population of around 248,422,956 people or around $7.69 \%$. Children in Indonesia who were detected to have developmental disorders before school age were $45.12 \%$. The number of children under five in South Sulawesi is 663,068 people $(3.48 \%)$. While in Palopo city the number of children under 
five in 2016 was 7,256 people (1.09\%) and in 2017 there were 8,431 people $(1,27 \%)$.

Growth and development are two events that are different but interrelated and difficult to separate, namely growth and development. Growth has an impact on the physical aspect, while development is related to the maturation of organ functions [2]. The growth and development of each child takes place according to general principles and each child has its own characteristics in its growth and development. Where the growth that occurs does not only include physical changes, but also changes in development in terms of thinking, feeling and behaving[2].

Considering the period from birth to the first five years of a child's life is a relatively short period and will not be repeated in a person's life. Child, the parent, caregiver, educator or community and health professionals should be able to take advantage of the opportunity to shape a child into quality child a high [3]. Therefore, parents need to seek aso that children grow and develop optimally in accordance with its potential, among others, through the efforts of stimulation, Detection and Early Intervention Growth in infants[4].

Most psychologists, especially cognitivists (cognitive psychologists) believe that the process of human cognitive development begins at birth. Provisions and basic capital for human development, namely motor and sensory capacities, are to some extent also influenced by the activities of the cognitive domain[5].

The term cognitive comes from the word cognition which is equivalent to knowing, which means knowing. In a broad sense, cognition is the acquisition, arrangement and use of knowledge. Furthermore, cognitive can also be interpreted as the ability to learn or think or intelligence, namely the ability to learn new skills and concepts, skills to understand what is happening in their environment, and skills to use memory and solve simple problems [6].
The connection of brain cells to a baby's development only begins after he is five months old when his sensory abilities (such as seeing and hearing) really begin to appear. According to cognitive psychologists, the utilization of cognitive capacity has started since humans began to utilize their motor and sensory capacities. But only the way and intensity of the use of the capacity of the cognitive domain is still not clear [7].

Knowledge of parents, especially mothers, is very important for the formation of an action. The basic needs for children's growth and development are mainly fulfilled by mothers, family members and the surrounding environment. Efforts to meet these basic needs are carried out through adequate, continuous interaction, according to age stages. The closer and more often the factors in the environment interact with children, the greater the role of these factors in determining the quality of children's growth and development [8].

Cognitive development in toddlers is directed at developing auditory (hearing), visual (seeing), tactile (touching textures), kinesthetic (hand movements / fine motor), arithmetic (numbers), geometry (shapes and sizes) and science (experiments) [5].

In a survey on the growth and development of children under five by means of multi-stage random sampling in a sub-district in East Jakarta, it was found that a $25.5 \%$ developmental delay was found in toddlers.

Kusuma's research (2012) concluded that there is a relationship between the mother's level of knowledge about child growth and development and the fine motor development of toddlers.

Data sourced from the Mungkajang Public Health Center in Palopo City shows that the number of children under five in 2017 was 534 people $(6.33 \%)$, in 2018 there were $479(5.68 \%)$ and in 2019 the January June period was 465 people $(5.51 \%)$ [8].

The researcher interviewed a mother who has a 5-year-old toddler with the initials "A" on August 9, 2019 in the 
working area of the Mungkajang Health Center, where the toddler has not been able to show the normality of language development in accordance with Denver II, namely the words are not all understandable.

Based on the above background, the researcher is interested in raising the title of the relationship between mother's knowledge about toddler growth and toddler cognitive development in the working area of Mungkajang Public Health Center, Palopo City.

\section{METHODS}

This research is a quantitative study with approach, cross sectional which is a type of research that emphasizes the time of measurement or observation of independent and dependent variable data only once at a time or measurement at the same time. In this study, the sampling technique used is purposive sampling, namely sampling by determining specific characteristics that are in accordance with the research objectives with a total sample of 82 people.

\section{RESULTS}

Table1: Frequency Distribution of Maternal Age at Mungkajang Public Health Center, Palopo city

\begin{tabular}{|l|c|c|}
\hline Mother's age & Frequency & Percent \\
\hline$<30$ years & 38 & 46.3 \\
\hline 31-40 Years & 34 & 41.5 \\
\hline$>40$ years & 10 & 12.2 \\
\hline Education & Frequency & Percent \\
\hline Elementary school & 10 & 12.2 \\
\hline Junior high school & 18 & 22 \\
\hline Senior high school & 47 & 57.3 \\
\hline College & 7 & 8.5 \\
\hline Toddler age & Frequency & Percent \\
\hline 1 year & 29 & 35.4 \\
\hline 2 years & 21 & 25.6 \\
\hline 3 years & 15 & 18.3 \\
\hline 4 years & 10 & 12.2 \\
\hline 5 years & 7 & 8.5 \\
\hline Gender Toddler & Frequency & Percent \\
\hline Male & 48 & 58.5 \\
\hline Female & 34 & 41.5 \\
\hline
\end{tabular}

Results of this study will be divided into two parts, namely univariate analysis to provide an overview of the frequency and distribution of respondents including maternal age, mother's education, age of toddlers, gender of toddlers, maternal knowledge and cognitive development of toddlers. Bivariate analysis to provide an explanation of the relationship between the variables studied.

Table 1 shows that from 82 respondents, 38 people $(46.3 \%)$ aged $<30$ years, 34 people $(41.5 \%)$ aged between 31 40 years and 10 people $(12.2 \%)$ aged $>40$ years.

Based on educational level, the more the upper secondary school education is 47 respondents $(57.3 \%)$ and terndah at the level of higher education, namely 7 respondents $(8.5 \%)$

Based on the age of the children, it was found that more at the age of 1 year i.e. 29 people $(35.4 \%)$ and the lowest was at the age of 7 years, namely 7 people $(8.5 \%)$.

Based on gender, there were more males, namely $58.5 \%$ compared to females, which was only $41.5 \%$

Table 2: Analysis of the Relationship of Knowledge with Toddler Cognitive Development at Mungkajang Health Center, Palopo city

\begin{tabular}{|c|c|c|c|c|c|c|c|}
\hline Knowledge & \multicolumn{3}{|c|}{ Cognitive Development } & \multicolumn{2}{|c|}{ Total } & \multirow{2}{*}{ P } \\
\cline { 2 - 6 } & Abnormal & \multicolumn{2}{|c|}{ Normal } & \multicolumn{2}{|c|}{} \\
\cline { 2 - 6 } & $\mathbf{n}$ & $\mathbf{\%}$ & $\mathbf{n}$ & $\mathbf{\%}$ & $\mathbf{n}$ & $\mathbf{\%}$ & \\
\hline Good & 1 & 1,2 & 50 & 61 & 51 & 62,2 & 0,000 \\
\hline Less & 13 & 15,8 & 18 & 22 & 31 & 37,8 & \\
\hline Total & $\mathbf{1 4}$ & $\mathbf{1 7}$ & $\mathbf{6 8}$ & $\mathbf{8 3}$ & $\mathbf{8 2}$ & $\mathbf{1 0 0}$ & \\
\hline
\end{tabular}

Table. 2 shows that from 82 respondents, 51 respondents $(62.2 \%)$ have good knowledge, of which there are 50 people $(61 \%)$ whose toddlers do not experience cognitive development disorders and 1 person (1.2\%) whose toddlers experience cognitive developmental disorders. Meanwhile, of the 31 respondents $(37.8 \%)$ who had poor knowledge, there were 18 people $(22 \%)$ whose toddlers did not experience cognitive developmental disorders and 13 people (15.9\%) who had cognitive developmental disorders.

The results of statistical tests using the test chi-square showed that the $\mathrm{p}$-value = 0.000 was smaller than the value of $=0.05$, which means that there is a relationship between mother's knowledge about growth and development of toddlers and cognitive development of toddlers in the working area of Mungkajang Public Health Center, Palopo City. 


\section{DISCUSSION}

This discussion explains the results of research, theories that are in line with or that are not in line with the results of previous studies and studies that are in line or not in line with. This sub-chapter also explains the limitations of the study and the implications of research on health, especially nursing.

The results showed that from 82 respondents, 51 respondents $(62.2 \%)$ had good knowledge and 31 respondents $(37.8 \%)$ had poor knowledge.

Knowledge is the result of knowing and this occurs after people have sensed certain objects. Knowledge occurs through the five human senses, namely the senses of sight, hearing, smell, taste and touch. Most of human knowledge is obtained through the eyes and ears [9].

The results of this study are in line with the results of the research of Kharisma \& Efni (2017) which shows that most of the respondents have a good level of knowledge as many as 18 respondents (47.4\%)[10].

The researcher assumes that the number of respondents who have good knowledge $(62.2 \%)$ indicates that the respondents get a lot of information about the growth and development stimulation given to their children and also the cognitive development of toddlers according to their stage of development. Information obtained by respondents from various sources of information such as $\mathrm{TV}$, posyandu and others. The more information the respondent gets, the better the level of knowledge the respondent has.

The results showed that from 82 toddlers, as many as 68 people $(82.9 \%)$ did not have cognitive development disorders and 14 people $(17.1 \%)$ had cognitive development disorders.

According to Desmita (2010) Cognitive development is one aspect of human development related to understanding (knowledge), namely all psychological processes related to how individuals learn and think about their environment [11].
The results of this study are in line with the results of research b. Sudarti \& Fauziah (2014) entitled the relationship between mother's level of knowledge about growth and development of toddlers with cognitive development of toddlers 1-3 years old, showing that most respondents do not have cognitive development disorders in their toddlers as many as 24 toddlers $(55.8 \%)$ [12].

The researcher assumes that the results of the study show that the number of respondents under five who do not experience motor development disorders $(82.9 \%)$ is because most of the respondents have good knowledge in providing stimulation for cognitive development.

Relationship between Knowledge and Cognitive Development of Toddlers, The results of statistical tests using the test chi-square show that the $\mathrm{p}$-value $=0.000$ is smaller than the value of $=0.05$, which means that there is a relationship between mother's knowledge about growth and development of toddlers and cognitive development of toddlers in the working area of Mungkajang Health Center Palopo in 2019.

Knowledge is one of the most important factors so that a person can act to take the right action. Without good knowledge of course it is difficult for someone to be able to take the right action according to the situation they face (Notoadmodjo, 2012) A mother who has good knowledge about the growth and development of toddlers certainly has the ability to act better and more carefully than mothers who do not or do not. lack of knowledge about toddler growth and development. As stated by Morgan (2002 in Muslimin, 2015) that any relatively permanent change in behavior occurs as a result of experiential training because knowledge is a result of knowing that occurs after sensing an object.

In raising toddlers, parents need to understand what is going on with toddlers and recognize what toddlers need for their development, as well as what things must be 
done to meet these needs so that parents can make the right decisions to optimize their toddler's cognitive development.

Cognitive development is how children adapt and interpret objects and events around them. How children learn the characteristics and functions of objects, such as toys, furniture and food as well as social objects such as self, parents and friends [11].

The results of this study are in line with the results of research by Sudarti \& Fauziah (2014) which shows that there is a relationship between There is a significant relationship between mother's knowledge about child development and cognitive development of toddlers 1-3 years old at Posyandu Jinten 12 RW XII Badran, Bumijo Village, Jetis District, Yogyakarta City[12].

Based on the results of the study which showed that respondents who had good knowledge but their toddlers experienced growth and development disorders as much as 1 person $(1.2 \%)$ due to the act of giving maternal stimulation that was not good, it means that even though knowledge is good but not followed by appropriate actions, the growth and development disorders of toddlers remain. could occur. While those with poor knowledge but their toddlers do not experience cognitive impairment as many as 18 people $(22 \%)$, this is because in caring for toddlers the respondents are assisted by parents who have experience on how to care for and stimulate the development of toddlers.

In accordance with what was stated by Warsito et al in Hati and Lestari (2016) which stated that the provision of stimulation will be effective if it pays attention to the needs of children according to the stages of development. Stimulation of growth and development is a factor that affects the development of toddlers. The interaction between the environment and stimuli can help the development of the brain in compiling the neural structure [13].

\section{CONCLUSION}

The results of the study can be concluded that knowledge has a significant relationship to cognitive development in toddlers. Referring to the results of this study, it can be used as a reference by health agencies to always plan and provide supervision of nursing services that can prevent cognitive development disorders in toddlers.

\section{Acknowledgement: None}

\section{Conflict of Interest: None}

\section{Source of Funding: None}

\section{REFERENCE}

1. Kemendikbud RI (2017) http://paud.kemdikbud.go.id/2017/08/07/ind onesia-peringkat-101-dunia-tumbuhkembang-anak/ diakses pada tanggal 26 Agustus 2019

2. Zulhidda (2013) Pengetahuan Ibu Tentang Tumbuh Kembang Bayi Usia 0-12 Bulan Di Klinik Cahaya Medan Brayan. Skripsi USU.

3. Wijaya, A. M. (2009). Pentingnya stimulasi, deteksi, dan intervensi dini tumbh kembang (SDIDTK atau "SIDIDITK”) anak. Jakarta: Depdiknas

4. Rahayu, S. (2012). Karakteristik ibu balita kaitannya dengan pelaksanaan stimulasi, deteksi dan intervensi dini tumbuh kembang anak balita http://jurnal.poltekkessolo.ac.id/index.php/Int/article/download/59 149 diakses tanggal 29 Juli 2019

5. Khadijah. (2016). Perkembangan Kognitif Anak Usia Dini. Perdana Publishing

6. Pudjiati, S.R.R dan Masykouri, AlZena, (2011). Mengasah Kecerdasan di Usia 0-2 Tahun. Jakarta: Dirjen PAUDNI.

7. Jahja, Y. (2013) Psikologi Perkembangan. Edisi Pertama. Jakarta: Kencana Prenadamedia Group

8. Kusuma Rohmilia (2012) Hubungan Antara Tingkat Pengetahuan Ibu Tentang Tumbuh Kembang Anak Dan Perkembangan Motorik Halus Balita Di Wilayah Kerja Puskesmas Penumping Surakarta.

9. Notoatmodjo S., (2012). Kesehatan Mastarakat Ilmu dan Seni. Rineka Cipta. Jakarta 
Santi et.al. Relationship capital knowledge about developmental cognitive development toddlers with a toddler in Puskesmas Mungkajang Palopo

10. Kharisma, M., \& Efni, N. (2017). Hubungan petahuan ibu tentang tumbuh kembang dengan perkembangan anak usia 3-4 tahun di kelompok bermain golden kids di Kecamatan Telanai Pura Kota Jambi. Jurnal akademika baiturrahman. STIKBA Jambi

11. Desmita. (2010). Psikilogi Perkembangan. Bandung: PT Remaja Rosdakarya.

12. Sudarti., \& Fauziah, A. (2014). Hubungan antara tingkat pengetahuan ibu tentang tumbuh kembang balita dengan perkembangan kognitif balita 1-3 tahun di Posyandu Jinten 12 RW XII Badran, Bumijo, Jetis, Yogyakarta. Jurnal medika respati. Yogyakarta
13. Hati, Febrina Suci \& Lestari, Prasetya. (2016). Pengaruh Pemberian Stimulasi pada Perkembangan Anak Usia 12-36 Bulan di Kecamatan Sedayu, Bantul. Jurnal Ners and Midwifery Indonesia

How to cite this article: Santi, Gafur A. Relationship capital knowledge about developmental cognitive development toddlers with a toddler in Puskesmas Mungkajang Palopo. International Journal of Science \& Healthcare Research. 2021; 6(3): 285-290. DOI: https://doi.org/10.52403/ijshr.20210750 